\title{
PENGARUH TANGIBLE DAN RESPONSIVENESS TERHADAP KEPUASAN PELANGGAN PADA GARUDA PLAZA HOTEL
}

\author{
Ade Irma $^{1)}$ \& Hendra Saputra ${ }^{2)^{*}}$ \\ ${ }^{1}$ Fakultas Ekonomi, Universitas Negeri Medan \\ ${ }^{2}$ Fakultas Ekonomi, Universitas Negeri Medan \\ Email : ${ }^{1}$ adeeirma579@gmail.com, ${ }^{2}$ hensap75@gmail.com
}

\begin{abstract}
Abstrak
Penelitian ini bertujuan untuk mengetahui pengaruh tangible dan responsiveness terhadap kepuasan pelanggan pada Garuda Plaza Hotel Medan. Penelitian ini menggunakan metode kuantitatif dengan teknik pengambilan sampel menggunakan teknik Simple Random Sampling, dengan jumlah sampel sebanyak 100 orang yang pernah menginap di Garuda Plaza Hotel Medan. Teknik pengumpulan data dalam penelitian ini dilakukan dengan cara menyebarkan kuesioner yang pengukurannya dengan skala likert dan diolah secara statistik menggunakan analisis regresi linear berganda dan pengujian hipotesis dengan uji $\mathrm{F}$, uji t dan koefisien determinasi yang sebelumnya data telah diuji menggunakan uji validitas, uji reliabilitas dan uji asumsi klasik. Pengolahan data menggunakan program SPSS 21.0 for windows.

Berdasakan pengolahan data diperoleh persamaan regresi $\mathrm{Y}=10,507+0,344 \mathrm{X}_{1}+0,390 \mathrm{X}_{2}+$ e yang artinya jika tangible dan responsiveness dikondisi konstan maka kepuasan pelanggan adalah sebesar 10,507. Selanjutnya nilai koefisien determinasi menunjukkan nilai sebesar 0,461 yang berarti bahwa tangible dan responsiveness berpengaruh terhadap kepuasan pelanggan sebesar $46,1 \%$ sedangkan sisanya dipengaruhi oleh variabel lain. Secara parsial (uji t) tangible dan responsiveness berpengaruh positif dan signifikan terhadap kepuasan pelanggan pada Garuda Plaza Hotel Medan. Uji $\mathrm{F}$ ( simultan) diperoleh hasil $\mathrm{F}_{\text {hitung }}>\mathrm{F}_{\text {tabel }}(41,482>3,09)$ dan nilai signifikannya $0,000<0,05$. Dengan demikian dapat disimpulkan bahwa ada pengaruh positif dan signifikan antara tangible dan responsiveness terhadap pelanggan pada Garuda Plaza Hotel Medan.
\end{abstract}

Kata Kunci: tangible, responsiveness, kepuasan pelanggan. 


\section{PENDAHULUAN}

Bagi Indonesia, sektor pariwisata merupakan sektor yang paling penting dalam perekonomian, baik sebagai sumber penghasil devisa negara, pencipta lapangan kerja dan kesempatan berusaha, serta pemerataan pendapatan. Semakin banyaknya wisatawan yang berkunjung ke suatu obyek wisata atau semakin berkembangnya suatu daerah karena pariwisatanya maka salah satu yang dibutuhkan adalah jasa penginapan atau hotel.

Menurut Suryadharma \& Nurcahya (2015) Perhotelan merupakan salah satu akomodasi komersial yang menyediakan berbagai pelayanan (service) seperti, pelayanan penginapan, penyiapan makanan dan minuman bagi siapa saja yang memerlukan. Hotel memiliki peran penting dalam kemajuan pariwisata di Indonesia, hal ini tentunya membuka peluang bisnis khususnya bagi pengusaha yang bergerak dibidang sektor jasa pariwisata terutama dibidang perhotelan.

Bisnis hotel di kota Medan-Sumatera Utara memiliki perkembangan dan pertumbuhan yang terus meningkat. Berkembangnya bisnis hotel di kota Medan tidak terlepas dari permintaan pasar. Keadaan demikian tentunya akan diikuti pula dengan persaingan yang semakin tinggi antar perusahaan jasa perhotelan yang ada. Kepuasan konsumen merupakan hal yang harus diperhatikan oleh perusahaan untuk mempertahankan konsumen agar tidak berpindah ke perusahaan yang lain. Menurut Suryadharma \& Nurcahya (2015) Kualitas pelayanan merupakan kunci kesuksesan bisnis perhotelan dan ada dimensi yang perlu diperhatikan, kelima dimensi tersebut antara lain bukti fisik (Tangibles), kehandalan (Reability), daya tanggap (Responsiveness), jaminan (Assurance), dan empati (Emphaty).

Garuda Plaza Hotel adalah salah satu hotel bintang 4 (empat) di kota Medan yang beralamat di Jalan Sisingamangaraja No. 18, Kecamatan Medan Kota. Hotel ini memiliki jumlah kamar dengan total 287 kamar dan didukung dengan fasilitas lainnya seperti meeting room \& ball room, restoran, cafe, kolam renang, fitness center, fasilitas Wi-Fi, layanan spa and massage. Berikut merupakan data pengunjung pada Garuda Plaza Hotel Medan setiap bulannya.

Tabel 1

Jumlah Pengunjung Garuda Plaza Hotel Medan

Januari-Desember 2019

\begin{tabular}{|l|c|}
\hline \multicolumn{1}{|c|}{ Bulan } & $\begin{array}{c}\text { Jumlah } \\
\text { Pengunjung }\end{array}$ \\
\hline Januari & 7.642 \\
\hline Februari & 7.662 \\
\hline Maret & 10.178 \\
\hline April & 11.553 \\
\hline Mei & 5.627 \\
\hline Juni & 8.038 \\
\hline Juli & 7.926 \\
\hline Agustus & 8.925 \\
\hline September & 8.713 \\
\hline Oktober & 9.212 \\
\hline November & 11.991 \\
\hline Desember & 7.966 \\
\hline Total & $\mathbf{1 0 5 . 4 3 3}$ \\
\hline
\end{tabular}

Sumber: Garuda Plaza Hotel Medan (2020)

Berdasarkan data di atas dapat dilihat bahwa jumlah pengunjung pada Garuda Plaza Hotel Medan, berfluktuasi setiap bulannya. Biasanya pemicu kenaikan jumlah pengunjung disebabkan oleh perayaan-perayaan besar pada bulan tersebut, namun jumlah pengunjung yang berfluktuasi juga dapat disebabkan oleh faktor kualitas pelayanan sehingga berpengaruh terhadap kepuasan pelanggan yang masih kurang optimal sehingga pengunjung masih mempertimbangkan hotel pesaing sebagai pilihannya. Penelitian yang dilakukan oleh Susepti, dkk. (2017) menyatakan bahwa pelayanan yang berkualitas dan sesuai dengan kebutuhan tamu dapat berdampak pada tingkat kepuasan tamu. Tingkat kepuasan tamu tersebut terhadap kualitas pelayanan yang diberikan merupakan penilaian menyeluruh atas keunggulan suatu jasa terkait fasilitas, pelayanan, dan respon karyawan yang baik, dapat memberikan kesan atau pengalaman yang baik bagi tamu, 
sehingga bisa memunculkan rasa percaya dan loyal terhadap hotel. Sedangkan penelitian yang dilakukan oleh Lubis (2013) menyatakan bahwa variabel yang paling berpengaruh terhadap kepuasan pelanggan adalah tangible kemudian diikuti responsiveness.

Menurut Suparyanto dan Rosad (2015:135) Tangible atau bukti fisik yaitu kemampuan suatu perusahaan dalam menunjukkan eksistensi bukti fisik kepada pihak eksternal. Tangible atau bukti fisik ini antara lain gedung, mesin, peralatan, teknologi, lahan parkir, kebersihan, serta penampilan pegawai.

Hasil observasi yang diamati pada salah satu situs OTA (Online Travel Agent) mengenai ulasan oleh konsumen yang pernah berkunjung ke Garuda Plaza Hotel menyatakan bahwa banyak konsumen yang mengeluh mengenai ruang kamar yang tidak bersih, jaringan Wi-Fi yang lambat, AC (Air Conditioner) yang tidak berfungsi dengan baik dan rooms furniture yang tidak up to date (masa kini). Sehingga membuat pengunjung tidak merasakan kepuasan saat menginap di Garuda Plaza Hotel karena fasilitas yang diberikan masih kurang baik seperti yang seharusnya dimiliki oleh hotel bintang 4 (empat).

Selain tangible (bukti fisik), kepuasan konsumen juga dapat diciptakan melalui responsiveness (daya tanggap) dari karyawan hotel. Menurut Parasuraman, et.al. (dalam Rambat Lupiyoadi, 2001:148) Responsiveness atau ketanggapan yaitu suatu kemauan untuk membantu dan memberikan pelayanan yang cepat (responsif) dan tepat kepada pelanggan, dengan penyampaian informasi yang jelas. Membiarkan konsumen menunggu tanpa adanya suatu alasan yang jelas menyebabkan persepsi yang negatif dalam kualitas pelayanan.

Hasil observasi yang diamati pada salah satu situs OTA (Online Travel Agent) mengenai ulasan konsumen yang pernah berkunjung ke Garuda Plaza Hotel menyatakan bahwa karyawan hotel kurang ramah serta kurang mampu untuk membangkitkan rasa kepercayaan konsumen, seperti keluhan konsumen mengenai AC (Air Conditioner) yang rusak tidak ditanggapi dengan baik oleh karyawan hotel, tidak membantu pelanggan yang kesulitan membawa barang pribadinya, proses check-in yang lama, layanan penyediaan makanan yang lama. Hal seperti ini tentunya bukanlah harapan konsumen, sehingga kepuasan konsumen belum tercapai dengan maksimal. Sebagai hotel bintang 4 (empat), Garuda Plaza Hotel seharusnya memiliki karyawan yang lebih profesional dalam melayani setiap konsumen.

\section{TINJAUAN PUSTAKA}

\section{Kepuasan Pelanggan}

Kotler dan Keller (2008:138-139) Kepuasan (satisfaction) adalah perasaan senang atau kecewa seseorang yang timbul karena membandingkan kinerja yang dipersepsikan produk (atau hasil) terhadap ekspektasi mereka. Jika kinerja gagal memenuhi ekspektasi, pelanggan akan tidak puas. Jika kinerja sesuai ekspektasi, pelanggan akan puas. Jika kinerja melebihi ekspektasi, pelanggan akan sangat puas dan senang. Engel, et.al. (dalam Tjiptono, 2008:38) Kepuasan pelanggan merupakan evaluasi purnabeli dimana alternatif yang dipilih sekurangkurangnya memberikan hasil (outcome) yang sama atau melampaui harapan pelanggan, sedangkan ketidakpuasan timbul apabila hasil yang diperoleh tidak memenuhi harapan pelanggan.

Menurut Tjiptono (dalam Imansyah dan Haris, 2017) indikator kepuasan pelanggan terdiri dari: (1) Kesesuaian harapan, (2) Minat berkunjung kembali, (3) Kesediaan merekomendasikan.

\section{Tangible (Bukti Fisik)}

Parasuraman, et.al. (dalam Rambat Lupiyoadi, 2001:148) Tangible atau bukti fisik yaitu kemampuan suatu perusahaan dalam menunjukkan eksistensinya kepada pihak eksternal. Yang meliputi fasilitas fisik 
(gedung, gudang, dan lain sebagainya), perlengkapan dan peralatan yang dipergunakan (teknologi), serta penampilan pegawainya. Menurut Suparyanto dan Rosad (2015:135) Tangible atau bukti fisik yaitu kemampuan suatu perusahaan dalam menunjukkan eksistensi bukti fisik kepada pihak eksternal. Bukti fisik ini antara lain gedung, mesin, peralatan, teknologi, lahan parkir, kebersihan, serta penampilan pegawai. Menurut Tjiptono dan Chandra (2011:233) indikator tangible atau bukti fisik, yaitu: (1) Kemutakhiran peralatan dan teknologi, (2) Kondisi sarana, (3) Kondisi SDM perusahaan, (4) Keselarasan fasilitas fisik dengan jenis jasa yang diberikan.

\section{Responsiveness (Daya Tanggap)}

Menurut Suparyanto dan Rosad (2015:134) Responsiveness atau daya tanggap yaitu kebijakan untuk membantu dan memberikan jasa yang cepat (responsif), dan tepat kepada pelanggan, dengan penyampaian informasi yang jelas. Parasuraman (dalam Jasfar, 2005: 51) Responsiveness (daya tanggap), yaitu kemauan dan keinginan para karyawan untuk membantu dan memberikan jasa yang dibutuhkan konsumen. Membiarkan konsumen menunggu, terutama tanpa alasan yang jelas akan menimbulkan kesan negatif yang tidak seharusnya terjadi. Menurut Antreas (dalam Lubis, 2013) indikator responsiveness atau daya tanggap yaitu: (1) Informatif, (2) Kecepatan pelayanan, (3) Kesediaan membantu, (4) Sigap.

\section{Hipotesis}

H1: Terdapat pengaruh tangible terhadap kepuasan pelanggan pada Garuda Plaza Hotel Medan

$\mathrm{H} 2$ : Terdapat pengaruh responsiveness terhadap kepuasan pelanggan pada Garuda Plaza Hotel Medan

H3: Terdapat pengaruh tangible dan responsiveness terhadap kepuasan pelanggan pada Garuda Plaza Hotel Medan

\section{METODE PENELITIAN}

Penelitian ini dilakukan di Garuda Plaza Hotel Medan yang beralamat di Jl.
Sisingamangaraja No. 18, Kec. Medan Kota, Kota Medan, Sumatera Utara. Adapun penelitian ini dilakukan pada bulan Maret. Populasi dalam penelitian ini adalah seluruh pengunjung yang datang ke Garuda Plaza Hotel Medan dalam satu bulan terakhir yaitu bulan Desember sebanyak 7.966 orang. Dalam penelitian ini, penentuan ukuran sampel menggunakan rumus Slovin sehingga diperoleh sampel atau responden berjumlah 100 orang pengunjung.

Model penelitian yang digunakan dalam penelitian iini adalah dengan analisis regresi linear berganda. Model regresi linear berganda digunakan untuk menguji pengaruh dua variabel independen atau lebih terhadap variabel dependen. Pengolahan data dalam penelitian ini menggunakan metode analisis regresi linier berganda dengan menggunakan uji $t$ dan uji $F$, dimana dasar pengambilan keputusan adalah dengan melihat nilai perbandingan $F_{\text {hitung }}>F_{\text {tabel }}$ dan $t_{\text {hitung }}>$ $t_{\text {tabel }}$ sehingga hipotesis dapat diterima.

\section{HASIL DAN PEMBAHASAN}

\section{Analisis Regresi Linear Berganda}

Berdasarkan hasil perhitungan diperoleh hasil persamaan regresi linear berganda sebagai berikut:

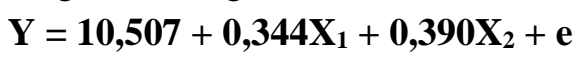

Yang berarti:

- Nilai konstanta Kepuasan Pelanggan (Y) sebesar 10,507 yang menyatakan jika tidak ada variabel X, yaitu Tangible dan Responsiveness maka Kepuasan Pelanggan adalah 10,507 dengan asumsi faktor lain konstan.

- Koefisien $X_{1}$ sebesar 0,344 menyatakan bahwa setiap terjadi peningkatan Tangible mempengaruhi Kepuasan Pelanggan sebesar 0,344 dengan asumsi faktor lain konstan.

- Koefisien X2 sebesar 0,456 menyatakan bahwa setiap terjadi peningkatan Reliability mempengaruhi Minat 
Berkunjung sebesar 0,456 dengan asumsi faktor lain konstan.

\section{Uji Hipotesis \\ Uji F (Simultan)}

Hasil pengujian terhadap uji $F$ diperoleh $F_{\text {hitung }}$ sebesar 41,482 lebih besar daripada $\mathrm{F}_{\text {tabel }}$ sebesar 3,09 dan dengan tingkat signifikansi $0,000<0,05$. Karena $F_{\text {hitung }}>F_{\text {tabel }}$ yang berarti bahwa Ho ditolak dan $\mathrm{Ha}$ diterima, sehingga dapat disimpulkan bahwa Tangible dan Responsiveness berpengaruh secara simultan (bersama-sama) terhadap Kepuasan Pelanggan pada Garuda Plaza Hotel Medan.

\section{Uji t (Parsial)}

Hasil dari uji statistik $\mathrm{t}$ (parsial) adalah sebagai berikut :

\section{a. Pengaruh $\mathrm{X}_{1}$ terhadap $\mathrm{Y}$}

Variabel Tangible memiliki thitung $>$ $t_{\text {tabel }}$ yaitu $4,437>1,98472$ dan taraf signifikansinya sebesar $0,000<0,05$. Hal tersebut berarti secara parsial dan secara signifikan Tangible berpengaruh positif terhadap Kepuasan Pelanggan. Berdasarkan hasil tersebut maka Ho ditolak dan $\mathrm{Ha}$ diterima.

\section{a. Pengaruh $\mathrm{X}_{2}$ terhadap $\mathrm{Y}$}

Variabel Responsiveness memiliki

$\mathrm{t}_{\text {hitung }}>\mathrm{t}_{\text {tabel }}$ yaitu 4,534 $>1,98472$ dan taraf signifikansi sebesar $0,000<0,05$. Hal tersebut berarti secara parsial dan secara signifikan Responsiveness berpengaruh positif terhadap Kepuasan Pelanggan. Berdasarkan hasil tersebut maka Ho ditolak dan Ha diterima.

\section{Koefisien Determinasi $\left(\mathbf{R}^{\mathbf{2}}\right)$}

Hasil uji koefisien determinasi diketahui bahwa besarnya angka $\mathrm{R}^{2}$ adalah 0,461 yang menunjukkan bahwa variabel independen yaitu Tangible $\left(\mathrm{X}_{1}\right)$ dan Responsiveness $\left(\mathrm{X}_{2}\right)$ menjelaskan pengaruh terhadap variabel dependen yaitu Kepuasan Pelanggan (Y) sebesar 0,461 atau 46,1\% sedangkan sisanya $53,9 \%$ dipengaruhi oleh faktor-faktor lainnya yang berasal dari luar variabel yang diteliti.

\section{Pembahasan Hasil Penelitian}

Hasil penelitian yang dilakukan menunjukkan bahwa Tangible berpengaruh positif dan signifikan terhadap Kepuasan Pelanggan. Adanya pengaruh positif ini dikarenakan tangible merupakan kebutuhan pelanggan yang berfokus pada bukti fisik yang dimiliki perusahaan yang akan mempengaruhi harapan pelanggan. Bukti fisik yang baik akan membuat harapan pelanggan menjadi lebih tinggi yang pada akhirnya akan menciptakan kepuasan pelanggan. Hal ini sejalan dengan penelitian terdahulu oleh M. Saleh Lubis (2013) yang menyatakan bahwa tangible berpengaruh positif dan signifikan terhadap kepuasan pelanggan.

Pelanggan juga memperhatikan responsiveness yang dimiliki staff atau karyawan dalam membantu pelanggan dan memberikan pelayanan yang cepat dan tanggap dalam hal menyampaikan informasi yang jelas mengenai pelayanan yang diberikan, kecepatan staff atau karyawan dalam menangani transaksi serta penanganan keluhan pelanggan. Staff atau karyawan yang memiliki responsiveness baik akan mampu menjalin hubungan yang baik antara perusahaan dengan pelanggan. Sebaliknya, mengabaikan dan membiarkan pelanggan menunggu tanpa alasan yang jelas menyebabkan persepsi yang negatif dalam kualitas pelayanan. Hasil penelitian yang dilakukan menunjukkan bahwa responsiveness berpengaruh positif dan signifikan terhadap kepuasan pelanggan. Hal ini sejalan dengan penelitian terdahulu oleh Widyastuti (2015) yang menyatakan bahwa responsiveness memiliki pengaruh yang signifikan terhadap kepuasan konsumen.

\begin{tabular}{llr}
\multicolumn{1}{c}{ Dengan demikian, dapat ditarik } \\
kesimpulan bahwa Tangible & dan \\
Responsiveness berpengaruh positif dan
\end{tabular} signifikan terhadap Kepuasan Pelanggan. Sehingga penelitian ini menyatakan bahwa secara simultan Tangible dan Responsiveness bersama-sama berpengaruh positif terhadap Kepuasan Pelanggan pada Garuda Plaza Hotel 
Medan. Hal ini juga menyimpulkan bahwa hipotesis ketiga diterima. Penting bagi suatu perusahaan untuk melakukan analisis kepuasan pelanggan, beberapa manfaat diantaranya yaitu untuk dapat meningkatkan loyalitas pelanggan, bereaksi dengan cepat terhadap perubahan yang terjadi di pasar serta mengidentifikasi peluang-peluang dan mengambil keuntungan dari peluang tersebut. Demi terciptanya hubungan jangka panjang antara pelanggan dengan perusahaan, maka perusahaan perlu memperhatikan Tangible dan Responsiveness untuk menciptakan kepuasan pelanggan.

\section{KESIMPULAN DAN SARAN}

Berdasarkan pembahasan di atas maka dapat ditarik kesimpulan bahwa (1) Tangible berpengaruh positif terhadap Kepuasan Pelanggan pada Garuda Plaza Hotel Medan, telah diuji dan terbukti dapat diterima kebenarannya. Dengan demikian hipotesis pertama diterima. (2) Responsiveness berpengaruh positif terhadap Kepuasan Pelanggan pada Garuda Plaza Hotel Medan. Hal ini menyatakan hipotesis yang dirumuskan peneliti yaitu Responsiveness diduga perpengaruh positif terhadap Kepuasan Pelanggan, telah diuji dan terbukti dapat diterima kebenarannya. Dengan demikian hipotesis kedua diterima. (3) Setelah peneliti melakukan penelitian mengenai Pengaruh Tangible dan Responsiveness terhadap Kepuasan Pelanggan pada Garuda Plaza Hotel Medan, maka dapat disimpulkan bahwa Tangible dan Responsiveness secara bersamasama (simultan) berpengaruh terhadap Kepuasan Pelanggan. Dengan demikian hipotesis ketiga diterima.

Berdasarkan kesimpulan di atas maka saran penelitian ini adalah: (1) Variabel Tangible memiliki pengaruh yang positif dan signifikan terhadap Kepuasan Pelanggan, namun beberapa hal masih harus diperhatikan seperti melakukan servis AC (Air Conditioner) secara berkala, meningkatkan kualitas perangkat dan jangkauan Wi-Fi, menggunakan rooms furniture yang up to date dan menjaga kebersihan dan kualitas linen yang digunakan agar pelanggan merasa lebih nyaman ketika menginap di Garuda Plaza Hotel Medan. (2) Variabel Responsiveness, perlu diperhatikan peningkatan kualitas pelayanan oleh staff hotel khususnya staff Front Office Departement karena mereka memiliki peran penting dalam menciptakan kesan pertama dan terakhir bagi tamu hotel yang akan menentukan keinginan dan motivasi tamu untuk kembali lagi atau tidak ke hotel. Penanganan keluhan pelanggan hotel dengan menerapkan metode HEAT (hear them out, empathize, apologize dan taking action dan follow up). Hear them out yang meliputi mendengarkan keluhan pelanggan dengan seksama. Empathize meliputi ikut merasakan apa yang dirasakan oleh pelanggan. Apologize yaitu meminta maaf kepada pelanggan atas ketidaknyamanan yang dirasakan. Sedangkan taking action dan follow up yaitu memberikan solusi dan melakukan tindakan yang tepat atas keluhan yang dirasakan oleh pelanggan hotel. Untuk meningkatkan kualitas pelayanan bisa dilakukan melalui workshop, kelas training atau program mentoring kepada staff hotel. (3) Kepada peneliti selanjutnya, karena penelitian ini mengangkat pengaruh Tangible dan Responsiveness yang memiliki nilai $\mathrm{R}$ Square rendah yaitu $46,1 \%$ dan sisanya $53,9 \%$ merupakan faktor lainnya diluar variabel yang diteliti dalam penelitian ini. Maka peneliti menyarankan adanya penelititan lebih lanjut dan lebih mendalam dengan menambahkan atau mengganti variabel bebas terhadap Kepuasan Pelanggan seperti empathy, assurance, reliability atau dimensi kualitas pelayanan yang lainnya.

\section{REFERENSI}

Ariani, D. Wahyu. 2009. Manajemen Operasi Jasa. Yogyakarta: Graha Ilmu.

Arikunto, Suharsimi. 2006. Prosedur Penelitian Suatu Pendekatan Praktik. Jakarta: Rineka Cipta. 
.2007. Manajemen

Penelitian. Jakarta: Rineka Cipta.

Budi, Agung Permana. 2013. Manajemen

Marketing Perhotelan.Yogyakarta

:Andi

Gunarathne, Umesh. 2014. Relationship between Service Qualitty and Customer Satisfaction in Sri Lankan Hotel Industry. International Journal of Scientific and Research Publications. Volume 4 Issue 11. Faculty of Management and Finance, University Of Ruhuna.

Hariyanto, Dedy dan Nindria Untarini. Pengaruh Kualitas Layanan Terhadap Kepuasan Pelanggan Hotel JW Marriott Surabaya. Jurnal Ilmu Manajemen. Volume 2 No. 4 Oktober 2014. Fakultas Ekonomi, Universitas Negeri Surabaya.

Imansyah dan Haris Irawan. Pengaruh Kualitas Pelayanan Terhadap Kepuasan Pelanggan Pada PT. Kerta Gaya Pusaka Cabang Kandangan. Jurnal Ilmiah Ekonomi Bisnis. Volume 3 No.3 November 2017. Fakultas Ekonomi, Universitas Achmad Yani Banjarmasin.

Jasfar, Farida. 2005. Manajemen Jasa: Pendekatan Terpadu. Bogor: Ghalia Indonesia.

Juliandi, Azuar, dkk. 2014. Metodologi Penelitian Bisnis. Medan: Umsu Press

Kotler, P. dan K. L. Keller. 2008. Manajemen Pemasaran. Jilid I. Jakarta: Erlangga.

Lamb, Hair, McDaniel. 2001. Pemasaran. Jakarta: Salemba Empat
Lubis, M. Saleh. Pengaruh Kualitas Pelayanan Terhadap Kepuasan Pelanggan Arumas Hotel Lubuk Sikaping. EJurnal Apresiasi Ekonomi. Volume 1 No. 2 Mei 2013. STIE Yayasan Pendidikan Pasaman.

Kuncoro, Mudrajad. 2013. Metode Riset Untuk Bisnis \& Ekonomi. Edisi 4. Jakarta: Erlangga.

Lupiyoadi, Rambat dan Hamdani, A. 2008. Manajemen Pemasaran Jasa. Edisi 2. Jakarta: Salemba Empat.

2011.

Manajemen Pemasaran

Jasa:

Teori dan Praktik. Jakarta: Salemba Empat.

Rao, Srinivas dan Padma Charan Sahu. 2013. Impact of Servive Quality on Customer Satisfaction in Hotel Industry. IOSR Journal Of Humanities And Social Science. Volume 18 Issue 5. Administrative Management College, Bangalore.

Riduwan. 2015. Skala Pengukuran VariabelVariabel Penelitian. Bandung: Alfabeta

Sunyoto, Danang. 2010. Uji Khi Kuadrat \& Regresi untuk Penelitian. Yogyakarta: Graha Ilmu.

Suparyanto, R.W. dan Rosad. 2015. Manajemen Pemasaran. Bogor: In Media.

Suryadharma, I.W. W. dan I. K. Nurcahya. 2015. Pengaruh Kualitas Pelayanan Pada Kepuasan Pelanggan Hotel Bintang Pesone Di Denpasar Timur. E-Jurnal Manajemen Unud.Volume 4 No. 4. Fakultas Ekonomi dan Bisnis, Universitas Udayana, Bali. 
Susepti, Amelia, dkk. Pengaruh Kualitas Pelayanan Terhadap Kepuasan dan Loyalitas Tamu Hotel (Studi Tentang Persepsi Tamu Hotel Mahkota Plengkung Kabupaten Banyuwangi). Malang: Jurnal Administrasi Bisnis. Volume 50 No. 5 September 2017. Universitas Brawijaya Malang.

Tjiptono, Fandy dan Chandra, Gregorius. 2011. Service, Quality \& Satisfaction. Yogyakarta: Andi. 2008. Strategi Bisnis. Yogyakarta: Andi.

Tjiptono, Fandy. 2014. Pemasaran Jasa. Yogyakarta: Andi

Umar, Husein. 2002. Metode Riset Bisnis. Jakarta: Gramedia

Wahjono, Sentot Imam. 2013. Manajemen Pemasaran Bank. Yogyakarta: Graha Ilmu.

Widyastuti, Niken Analisis Pengaruh Kualitas Pelayanan Terhadap KepuasanKonsumen (Survei Pada Tamu Pelanggan Yang Menginap di Harris \& Pop Hotels Denpasar).Jurnal Kajian Bisnis. Volume 23 No. 2 Juli 2015. STIE Widya Wiwaha Yogyakarta.

https://medankota.bps.go.id/ (15 Mei 2020)

www.traveloka.com (24 Desember 2019) 